\title{
Coronavirus disease 2019 (COVID-19): Current literature and status in India
}

\author{
Anbesh Jamwal $^{1 *}$, Sumedha Bhatnagar ${ }^{2}$, Prakarti Sharma ${ }^{2}$ \\ 1Department of Mechanical Engineering, Malaviya National Institute of Technology, J.L.N. Marg, Jaipur, Rajasthan-302017 \\ (India) \\ 2Department of Social Sciences and Humanities, Malaviya National Institute of Technology, J.L.N. Marg, Jaipur, Rajasthan- \\ 302017 (India)
}

\begin{abstract}
COVID-19 disease outbreak was started in the December, 2019 in the Wuhan city of China which is also known as the largest transportation hub of China. During the spring festival of China the situation become epidemic. Soon, the virus is imported to many regions including the low income countries. Till now, 234073 infected reported cases of the COVID-19 in the world with the total of 9840 deaths (March 20, 2020). The common symptoms of the COVID-19 are the cough, high fever, sore throat, fatigue and breathlessness. The disease is found to be mild in most of the people, some of cases reported to the pneumonia also with multi organ dysfunction and acute ARDS (acute respiratory distress syndrome). It is found that the incubation period for the infection is 2-14 days which is usually 4 days in maximum of cases. India has reported 283 cases of COVID-19 infections till now with 4 deaths. India is still at stage 2 on local transmission as per WHO report 60 . WHO reported 60 clearly stated that there is no community transmission occurred in India yet which can be prevented by the avoiding mass gathering and proper screening of the people. Govt. of India has taken many initiatives to minimize the spread of COVID-19 infection in the country. The infection rate of the COVID-19 in India remains low related to population size of the country. It is because of fast government action to quarantine the suspected people and shut down all its borders. There is a great slowdown in the global economy due to COVID-19 attack which is likely to costs around \$1 trillion. The spread of COVID-19 infection can be reduced by minimizing the $\mathrm{H}-\mathrm{H}$ transmissions. Still there is need of Anti-n-CoV drug development which can replace the supporting therapies for the treatment of infection.
\end{abstract}

Keywords: COVID-19; Coronavirus; SARS CoV, SARS CoV-2; novel CoV; India.

\section{Introduction}

Coronavirus (COVID-19) is one of the infectious diseases at present time which is caused by new virus. The Coronavirus was firstly characterized in 1960s with the symptoms of respiratory 
illness like the common cold identified by Canadian study 2001 in which approximately 500 patients were identified with the symptoms of virus and among them 17-18 cases were infected with corona virus strain with the polymerase chain reaction [1]. The earliest virus was identified known as infectious bronchitis virus which was in chicken and found in the patients also with the symptoms of common cold latterly considered as Human coronavirus OC43 and Human coronavirus 229E. with the time other members of this virus family were identified namely, SARS coronavirus in 2003 (9\% infected patients died rate), Human coronavirus NL63 in 2004 (mild to moderate upper infection in the respiratory system), HKU1in January, 2005 in the 2 patients of Hong Kong, MERS coronavirus in 2012 in Saudi Arabia with the similar flu like symptoms and SARS coronavirus-2 (COVID-19) in 2019 with most commonly symptoms of respiratory tract infections and common cold [2-3]. First case of coronavius (COVID-19) was observed in the Wuhan city of China. Wuhan, Hubei province of China is considered as the origin for the life threatening viral outbreak of Novel COVID-19 [4].Till 2002 coronavirus was considered as the non-fatal virus. In 2003 various health reports published among the globe have reported the spread the coronavirus in the various countries i.e. Singapore, United States of America, Hong Kong, Vietnam, Taiwan and Thailand [5]. COVID-19 was recognized as pandemic by WHO on the March-11, 2020. As of the March-21, 2020 around 276000 people are infected with COVID-19 virus in 180 countries with 88,000 recoveries and 11,300 deaths. The transmission of virus from one human to another is due to the respiratory droplets which are produced due to the coughing. The disease is transferred to another person by contact or inhalation with the infected droplets having the incubation period of two to fourteen days. India has reported 219 confirmed COVID-19 cases including 39 foreign national confirmed cases with 4 deaths and 23 recoveries. The aim of the present article is to give eye view of new identified virus. This article will help the low income countries to update the facts on COVID-19 and help them in the prevention from the infection.

\section{Origin and Spread of new coronavirus (COVID-19)}

First case of coronavius (COVID-19) was observed in the Wuhan city of China. Wuhan, Hubei province of China is considered as the origin for the life threatening viral outbreak of Novel COVID-19 [6]. Wuhan is the capital city of Hubei province which is also known as the one the major transportation hub in the China started serving the hospitals in their local regions with the pneumonia with unknown causes. The initial was traced with some of common exposures to the wholesale seafood market in Wuhan city which is also known for trading the living animals. After the SARS outbreak surveillance system was activated and respiratory related samples of suspected patients were sent to the labs for the investigations [7]. China notified the outbreak to WHO on December-31, 2019 and on January 1, 2020 seafood market of Huanan was closed till further notice. On January 7, 2020 it is found that coronavirus has the $>70 \%$ homogeneity with SARS-CoV and $>95 \%$ with the bat coronavirus [8]. Reports came from the Huanan also showed the positive result which clarifies that coronavirus was originated from the Wuhan city. Soon the 
number of cases stated increasing exponentially [9]. Generally the virus having four stages has shown in the Figure 1.

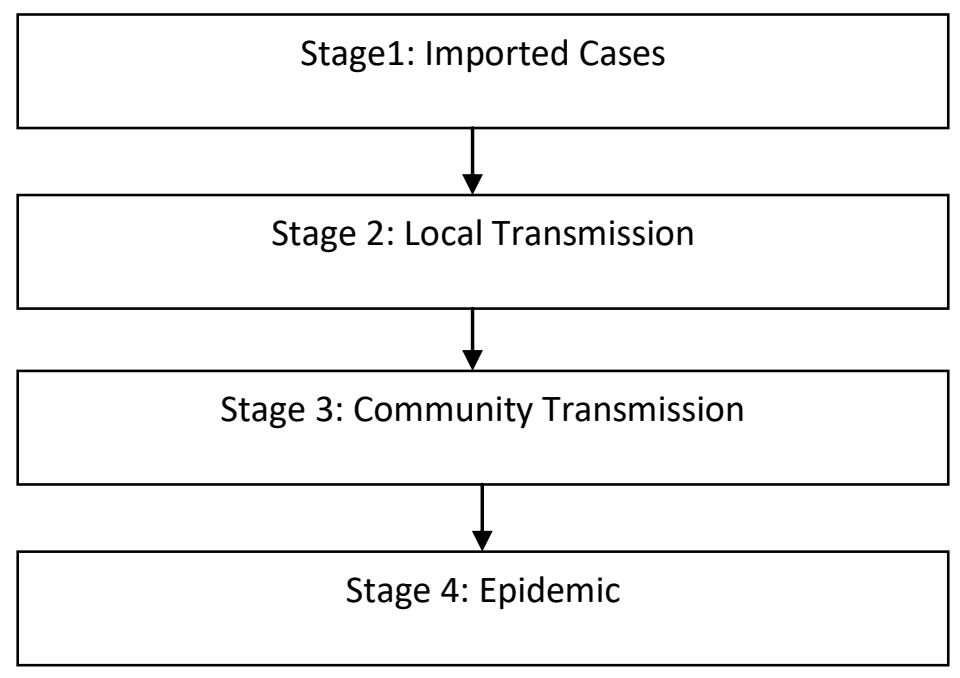

Figure 1: Four stages of COVID-19

Soon, the people who were not visited to animal market infected due to the human to human transmission which converted into the community transmission and Epidemic. China reported its first fatal case on January 11, 2020. Cases were reported in the other countries (South Korea, Japan and Thailand) and provinces of China in very short time in people who visited or returned from the Wuhan city during the outbreak. China government decided to lockdown the 11 million population of Wuhan city on January 23, 2020 with the restrictions for entry and exits from the Wuhan city. Due to the virus spread over Hubei province other cities were also lockdown. Airports of the different countries put the screening mechanisms to detect the infected people so that infected people returning from China can be detected and put into isolation till not tested or recovered from COVID-19. Countries like India who evacuated their citizens from the Wuhan city of other province from China by the special flights put the people in isolation for 14 days and tested for the COVID-19. Cases started increasing exponentially soon with the epidemic doubling time of 1.8 days in China. On February 12, 2020 China reported 2022 new cases in a single day. Also, 712 more people infected in the cruise ship named Diamond princess which was parked on the coast of Japan, in which 7 people are died. It is found that number of cases in China stated reducing with time but soon the number of cases started increasing exponentially in other countries like Italy, South Korea, United States of America, Thailand and Iran. At present as of (March 20, 2020) 2, 34,073 people are infected with COVID-19 in which 24247 are new cases with 9840 total deaths and 1061 new deaths. The Western region has 98349 confirmed cases with 1016 new cases having 3405 deaths with 28 new deaths. European Region has 104591 
confirmed cases with 17506 new cases and 4899 deaths with 816 new deaths. South-East Asia region having 918 confirmed cases with 261 new cases and 31 deaths with 8 new deaths. Eastern Mediterranean Region having 20759 confirmed cases of COVID-19 with 1254 new cases and having 1312 deaths with 151 new deaths. Region of Americas having 13271 confirmed cases with 4104 new cases and 8 deaths with 1 new death. It can be seen that South East Asia region and African region having less cases reported till now as compared to other regions which can be reduced by taking precaution and proper isolation. India reported its first confirmed case on January $30^{\text {th }}$, 2020 in Kerala state which was an imported case from China in a student who returned from the Wuhan University. The second case was also confirmed on February $2^{\text {nd }}, 2020$ in Kerala in an individual who was travelling regularly between India and China. The third case in India was also reported in the Kerala in Kasaragod in a patient returned from Wuhan city. As of now these all three patients have been recovered. As of March 21 ${ }^{\text {st }}, 2020$ MHFW (Ministry of health and family welfare) has reported 258 cases in India with 4 deaths.

\section{Microbiology of Coronavirus}

Coronavirus causes the acute and mild upper respiratory infections. Structure of coronvirus is spherical or pleomorphic enveloped particles which contains the single stranded RNA (Mr $6 \times 10^{6}$ ). In the structure RNA are associated with nucleoprotein [13]. The sub types of the coronavirus are an Alpha, Beta, Gamma and Delta virus which consists of the many serotypes [14]. Not all the coronvirus affect the humans some of them affect to human i.e. 229E-like and OC43-like and some affects the animals such as cats, pigs, mice and birds. Coronavirus are generally found to be mammalian and avian species as they resemble each other in the chemical structure and morphology [15]. There is no evidence till now that coronaviruses in human can be transmitted by the animals. Animal coronvirus attacks on the animal's tissues and results in many types of different diseases [16]. But in human coronavirus causes only mild upper respiratory infections which includes coomon colds. In rare occasions cornavirus infections associates with outbreaks of diarrhoea.

\section{Epidemiology}

As the virus is infecting at the very fast rate and still there is no vaccination is available for the COVID-19 so all the ages are susceptible. In the December, 2019 many pneumonia cases were found in the Wuhan City and latterly it found that the source of the infection was Huanan seafood market. The samples were collected and etiologic investigations were carried out in the patients having the similar viral symptoms. On January 22, $2020 \mathrm{CoV}$ has been declared as a virus which was originated from the wild bats and belonging to the SARS-CoV because both the COVID-19 and SARS-COV having the same beta coronavirus subgroup [17]. During the spring festival in China nearly 3 billion people travelled to countrywide which caused the favorable conditions for the infection transmission and resulted in the difficulties in the prevention of 
COVID-19. It is found that the virus is transmitted from one body to another body through the large droplets which are generated by the sneezing and coughing of a person who is infected from the virus. During the peak time of SARS CoV January 17- February 23, 2003 spring festival of China was held. Similarly, this year during the spring festival January 10- February 18, 2020 COVID-19 rapidly increases [18]. In COVID-19 Wuhan was the centre of epidemic having the 10 million of population also known as largest transportation hub in China. The numbers of travelers in the 2020 was the 3.11 billion while it was 1.82 billion in 2003 which set up the favorable conditions to spread up the virus in the Wuhan City and it becomes difficult to control the COVID-19 in China [19]. Patients of the COVID-19 can be infectious for long as the symptoms lasts in the body even after the clinical recovery. Some patients worked as the super spreader which turns out the conditions to be worst

\section{Virology of COVID-19}

Coronaviruses having the best genome structure among all the RNA viruses. Genome phylogenic and sequencing analysis of virus indicated that the COVID-19 is also a betacoronavirus which having the same subgenus as SARS-CoV with a different clade. COVID-19 having the similar receptor binding gene region structure like SARS CoV with the same receptor [20]. The virus is named as SARS CoV-2 by the Coronavirus study group of International committee on the Taxonomy of viruses [21]. It is also found that MERS virus which is another beta CoV appears to be more distantly related virus [22-23]. The primary source of the COVID-19 is still unknown. It is still not clear that this virus is transmitted from bats of some other mechanism [24]. The phylogenetic analysis from COVID-19 China reported that two different types of the SARS CoV-2 were identified in the analysis of 103 strains in which $70 \%$ was of L-type and 30\% was of S-type [25].

\section{Modes of Transmission}

Understanding of the transmission risk is still incomplete. Epidemiologic investigation from the Wuhan city at the beginning of the COVID-19 outbreak identified an initial association with the Huanan seafood market where the most of patients have visited [26]. However, human to human transmission was the main mode of infection transmission which is spread by the large respiratory droplets caused by sneezing and coughs [27]. With the droplets transmission from a infected person virus released in the respiratory secretions when an infected person sneeze or cough, it can be transmitted also if a person touches the infected person surface and then he touches his nose, mouth or eyes [28]. Droplets don't travel more than 6 feet and do not linger in the air. The rate of transmission depends from individual and location to location [29]. The joint report of WHO and China confirms that rate of secondary COVID-19 ranged from 1-5\% among 10,000 close contacts of the confirmed cases in China [30]. While in the United States, the symptomatic secondary attack rate was around $0.45 \%$ among 445 close contacts among the 10 confirmed cases [31]. Transmission of the individual within the incubation period has also discussed [32-35]. COVID-19 has been detected in the stool specimens and blood [36-37]. In 
some cases live virus has been cultured from the stool [38] but the Join report of WHO and China shows that fecal oral transmission was not appeared and not a significant factor in the spread of COVID-19 infection. The respiratory virus may contaminate the surfaces as long as up to 96 hours in case of screens of the smart phones [39].

\section{Characteristics}

The patient of COVID-19 has common symptoms of cough, high fever and fatigue. In some of the cases dyspnea and diarrhea are the uncommon features found. Many of the COVID-19 patients reported the bilateral abnormalities. It can be detected in the blood samples. Cases till now on COVID-19 not confirmed the existence of virus the feces and urine samples of the patients. (Guan et al. 2020) extracted the data of 1099 patients from the 552 hospitals from 30 provinces of China in which median age of patients was around 47 years out of which $41.9 \%$ were female. In the total patients around 67 patients the primary composite and end point occurred which were $6.1 \%$ of total patients investigated in the study in which $5 \%$ was admitted to the ICU and $1.4 \%$ died. It is also found that only $1.9 \%$ of total patients had contact with wildlife. Infected patients $(72.3 \%)$ who were not the residents of Wuhan city infected from the residents of Wuhan city in which $31.3 \%$ had visited the Wuhan city. The common symptoms among the patients were fever (88.7\% when they were hospitalized) and cough $(67.8 \%)$. The diarrhea was the uncommon symptom among the patients $(3.8 \%)$. In $83.2 \%$ of patients Lymphocytopenia was present [40].

\section{Current available literature studies on COVID-19}

COVID-19 was firstly observed in December, 2019 so there is less literature available on the infection. Also, the currently available treatments for the COVID-19 include the ventilation and intensive care. WHO has already accelerated the R\&D to accelerate the vaccines, diagnostics and therapeutics. (Ralph et al. 2020) explained the role of human to human transmission, vaccine readiness and cases related to travel history in the $\mathrm{n}-\mathrm{CoV}$ infection. (Lu et al. 2020) explained the general methods for the antiviral treatments for the $\mathrm{n}-\mathrm{CoV}$ which generally includes the screening and use of existing drugs, screening of the available databases for the drug development and redeveloping the drugs on the basis of understanding of n-CoV with the consideration of the current guidelines [41]. (Jiang et al. 2020) reviewed the clinical characteristics of the COVID-19 and concluded that most of the patients having the respiratory symptoms with fever [42]. (Sohrabi et al. 2020) suggested that there is need of mechanism to define the exact mechanism of $\mathrm{H}-\mathrm{H}$ transmission and $\mathrm{A}-\mathrm{H}$ transmission which will help in the development of the specific vaccination for the COVID-19 [43]. (Fang et al. 2020) conducted a systematic literature survey to syntheisize the critical data on the clinical traits of newly n-CoV from its outbreak to pandemic. 3470 confirmed cases were considered for investigation and found that most common symptom was fever $(83 \%)$ while $63.4 \%$ were considered fever as onset symptom. Patients from Hubei having higher ICU admission rate $(21.9 \%)$ as compared to the patient admitted outside the Hubei city [44]. (Rothan et al. 2020) concluded that phylogenetic 
analysis shows that $\mathrm{n}-\mathrm{CoV}$ is a potentially zoonotic virus which needs special attentions to minimize the transmissions in the susceptible populations. Commonly developed symptoms are diarrhea and fever. There is urgent need of drugs which can treat the COVID-19 [45]. (Pan et al. 2020) carried out a study to determine the change in the Chest CT findings which are associated with n-CoV pneumonia from the initial treatment to the final recovery of the patients. 21 patients which includes six males, fifteen females with the age group of 25-63 with the confirmed n-CoV were taken into the consideration. All the patients were tested with the $82 \mathrm{CT}$ scans with the range of 1-8 days. It was found that patient recovering from the $\mathrm{n}-\mathrm{CoV}$ shows the higher severity of 10 days after the initial appearance of symptoms [46]. (Zhang and Liu, 2020) suggested that antiviral treatments and $\mathrm{CoV}$ specific treatments were the useful treatments for the MERS and SARS which can be considered for the COVID-19 treatments. Other compounds should be chosen as the alternative option for the treatment which will help in the new drug design for the COVID-19 infection [47].

\section{Clinical Features}

\section{Incubation Period}

The incubation period for the COVID-19 virus is 14 days with most of cases occurs within the four to five days after the exposure [5,48]. In the study of the 1099 patients with confirmed COVID-19 symptoms the median incubation period was 4 days. The symptoms developed in $2.5 \%$ infected people within 2 days while $97.5 \%$ infected people took 11.5 days to develop the symptoms. The median incubation period was 5.1 days [40].

\section{Asymptomatic infections}

The frequencies of the asymptomatic infections are still unknown [49-51]. During the outbreak of COVID-19 all passenger and staff of a cruise ship were screened for the n-CoV in which around 17\% tested positive as of February 20, 2020 and about half of the 619 confirmed the COVID-19 cases were asymptomatic during the diagnosis stage [52]. Patients with the asymptomatic infection may have objective abnormalities [53]. In the study of 24 patients with asymptomatic infection go through the CT, 50\% having the patchy shadowing and 2-\% having the atypical imaging abnormalities. 5 patients developed the fever (low grade fever) without other typical symptoms after the few days of diagnosis [54].

\section{Spectrum of Illness severity}

The spectrum of the infections ranges from the mild to critical in most of the cases while not all the infections are severe [55]. Chinese centre for the disease control and prevention has mentioned in their report that in the 44,500 reported cases Mild or no mild pneumonia was detected in $81 \%$ of cases. In $14 \%$ of cases severe diseases i.e. hypoxia and dyspnea was observed with $24-48$ hours. $5 \%$ cases reported the critical diseases. The overall fatality rate was $2.3 \%$ and there was no death reported among the non-critical cases in the study [56]. 


\section{Impact of age on COVID-19}

All age groups are suspecitble in the COVID-19. But in the case studies it is found that most commonly affected age groups are middle age group and older age groups. Mostly of the hospitals with the confirmed COVID-19 cases having median age group of 49 to 56 years old [57-58]. Chinese centre for disease control and prevention confirms the 44,5000 infections in which the $87 \%$ of patients was between the 30 to 79 years old age group. In the United States of America around 2249 patients were diagnosed between the time period of Feb 12 to March 16, 2020 had the ICU, hospitalization and age information available [59]. A symptom occurrence in the children is appears to be uncommon and it happens it is usually mild in nature [60]. In China only two percentage of infections were appeared in the patients younger than 20 years old [56] in South Korea it was only $6.3 \%$ out of 8000 total infections [61-62]. In the another study from China six children between the age group of 1 to 6 years were admitted to hospital with COVID19 infection having the fever $>102.2^{\circ} \mathrm{F}$ with the cough out of which one was admitted to ICU. All the children have been recovered after the treatment [63]. 138 patients from Wuhan city was admitted to hospital and investigated after COVID-19 infections the observations are represented in the Table 1:

Table 1: Most common clinical features [59]

\begin{tabular}{|c|c|c|}
\hline S.No. & Clinical Feature & Percentage \\
\hline 1. & Fatigue & $70 \%$ \\
\hline 2. & Fever & $99 \%$ \\
\hline 3. & Anorexia & $40 \%$ \\
\hline 4. & Dry Cough & $59 \%$ \\
\hline 5. & Myalgias & $35 \%$ \\
\hline 6. & Sputum Production & $27 \%$ \\
\hline 7. & Dyspnea & $31 \%$ \\
\hline
\end{tabular}

\section{Confirmed Cases report (December- March 21, 2020)}

On December 31, 2019 China informed the World health organization regarding the Pneumonia cases in the Wuhan city. Till January 3, 2020 total of 44 cases of Pneumonia were detected. On January 7, 2020 Chinese authorities announced the isolation of new virus in Huanan seafood market in the Wuhan city which was named as COVID-19 or SARS CoV-2. Ministry of Public health Thailand reported first case of COVID-19 on January 13, 2020 which was imported from the Wuhan city. Ministry of health, labor and welfare Japan reported its first case January 15 , 2020 which was also imported from Wuhan city. Similarly, National IHR Focal point from the Korea reported its first case of COVID-19 on January 20, 2020. United Sates of America confirmed its first case on January 23, 2020. Vietnam reported its first case on January 24, 2020 
and this case was the first case which having not the travel history with China. One of the family member of the infected person having the travelling history of China. It was the first incidence when it is found that human to human transmission is occurs in the other countries. Government of Singapore confirms its first case on January 25, 2020. COVID-19 started spreading out at the very fast rate January 25, 2020 (Australia, French republic and Nepal), January 26, 2020 (Malaysia), January 27, 2020 (Canada), January 28, 2020 (Sri Lanka, Germany and Cambodia) January 29, 2020 (UAE), January 30, 2020 (Indian, Finland and Philippines), January 31, 2020 (Italy), February 1, 2020 (Spain, Russia, UK and Sweden), February 5, 2020 (Belgium), February 6, 2020 (Japan), February 14, 2020 (Egypt) and February 19, 2020 (Iran). The Table 2 shows the COVID status in the different region of the world and Table 3 shows the top 10 affected countries from COVID-19 as per March 20, 2020 [64].

Table 2: Total no. of cases Area wise in the world.

\begin{tabular}{|c|c|c|c|c|c|}
\hline Area & $\begin{array}{c}\text { Total number of } \\
\text { Confirmed } \\
\text { Cases }\end{array}$ & $\begin{array}{c}\text { Total no. of } \\
\text { new confirmed } \\
\text { cases }\end{array}$ & Total deaths & $\begin{array}{c}\text { Total new } \\
\text { deaths }\end{array}$ & Transmission type \\
\hline $\begin{array}{c}\text { Western } \\
\text { Pacific Region }\end{array}$ & 93324 & 999 & 3405 & 28 & $\begin{array}{c}\text { Mostly Local } \\
\text { Transmission }\end{array}$ \\
\hline $\begin{array}{c}\text { European } \\
\text { Region }\end{array}$ & 104549 & 17454 & 4899 & 816 & $\begin{array}{c}\text { Mostly Local } \\
\text { Transmission }\end{array}$ \\
\hline $\begin{array}{c}\text { South East } \\
\text { Asia Region }\end{array}$ & 918 & 261 & 31 & 8 & $\begin{array}{c}\text { Mostly Local } \\
\text { Transmission }\end{array}$ \\
\hline $\begin{array}{c}\text { Eastern } \\
\text { Mediterranean } \\
\text { region }\end{array}$ & 20712 & 1251 & 1312 & 151 & $\begin{array}{c}\text { Mostly Local } \\
\text { Transmission }\end{array}$ \\
\hline $\begin{array}{c}\text { Region of } \\
\text { Americas }\end{array}$ & 13150 & 4075 & 177 & 57 & $\begin{array}{c}\text { Mostly Local } \\
\text { Transmission }\end{array}$ \\
\hline \begin{tabular}{c} 
African Region \\
\hline
\end{tabular} & 454 & 102 & 8 & 1 & $\begin{array}{c}\text { Mostly Local } \\
\text { Transmission }\end{array}$ \\
\hline
\end{tabular}

Table 3: Top 10 infected Countries/ Areas in world from COVID-19

\begin{tabular}{|l|r|r|r|r|l|}
\hline $\begin{array}{l}\text { Country/ } \\
\text { Territory/Area }\end{array}$ & $\begin{array}{l}\text { Total confirmed } \\
\text { cases }\end{array}$ & $\begin{array}{l}\text { Total new } \\
\text { confirmed cases }\end{array}$ & Total deaths & $\begin{array}{l}\text { Total new } \\
\text { deaths }\end{array}$ & $\begin{array}{l}\text { Transmission } \\
\text { classification }\end{array}$ \\
\hline China & 81300 & 126 & 3253 & 11 & $\begin{array}{l}\text { Local } \\
\text { transmission }\end{array}$ \\
\hline Italy & 41035 & 5322 & 3407 & 429 & $\begin{array}{l}\text { Local } \\
\text { transmission }\end{array}$ \\
\hline Iran & 18407 & 1046 & 1284 & 149 & $\begin{array}{l}\text { Local } \\
\text { transmission }\end{array}$ \\
\hline Spain & 17147 & & 67 & 169 & $\begin{array}{l}\text { Local } \\
\text { transmission }\end{array}$ \\
\hline
\end{tabular}




\begin{tabular}{|l|r|r|r|r|l|}
\hline Germany & 10999 & 2801 & 20 & 8 & $\begin{array}{l}\text { Local } \\
\text { transmission }\end{array}$ \\
\hline France & 10877 & 1834 & 372 & 128 & $\begin{array}{l}\text { Local } \\
\text { transmission }\end{array}$ \\
\hline $\begin{array}{l}\text { United States of } \\
\text { America }\end{array}$ & 10442 & 3355 & 150 & 50 & $\begin{array}{l}\text { Local } \\
\text { transmission }\end{array}$ \\
\hline Republic of Korea & 8652 & 239 & 94 & 10 & $\begin{array}{l}\text { Local } \\
\text { transmission }\end{array}$ \\
\hline Switzerland & 3863 & 853 & 33 & 12 & $\begin{array}{l}\text { Local } \\
\text { transmission }\end{array}$ \\
\hline $\begin{array}{l}\text { The United } \\
\text { Kingdom }\end{array}$ & 3277 & 647 & 144 & 41 & $\begin{array}{l}\text { Local } \\
\text { transmission }\end{array}$ \\
\hline
\end{tabular}

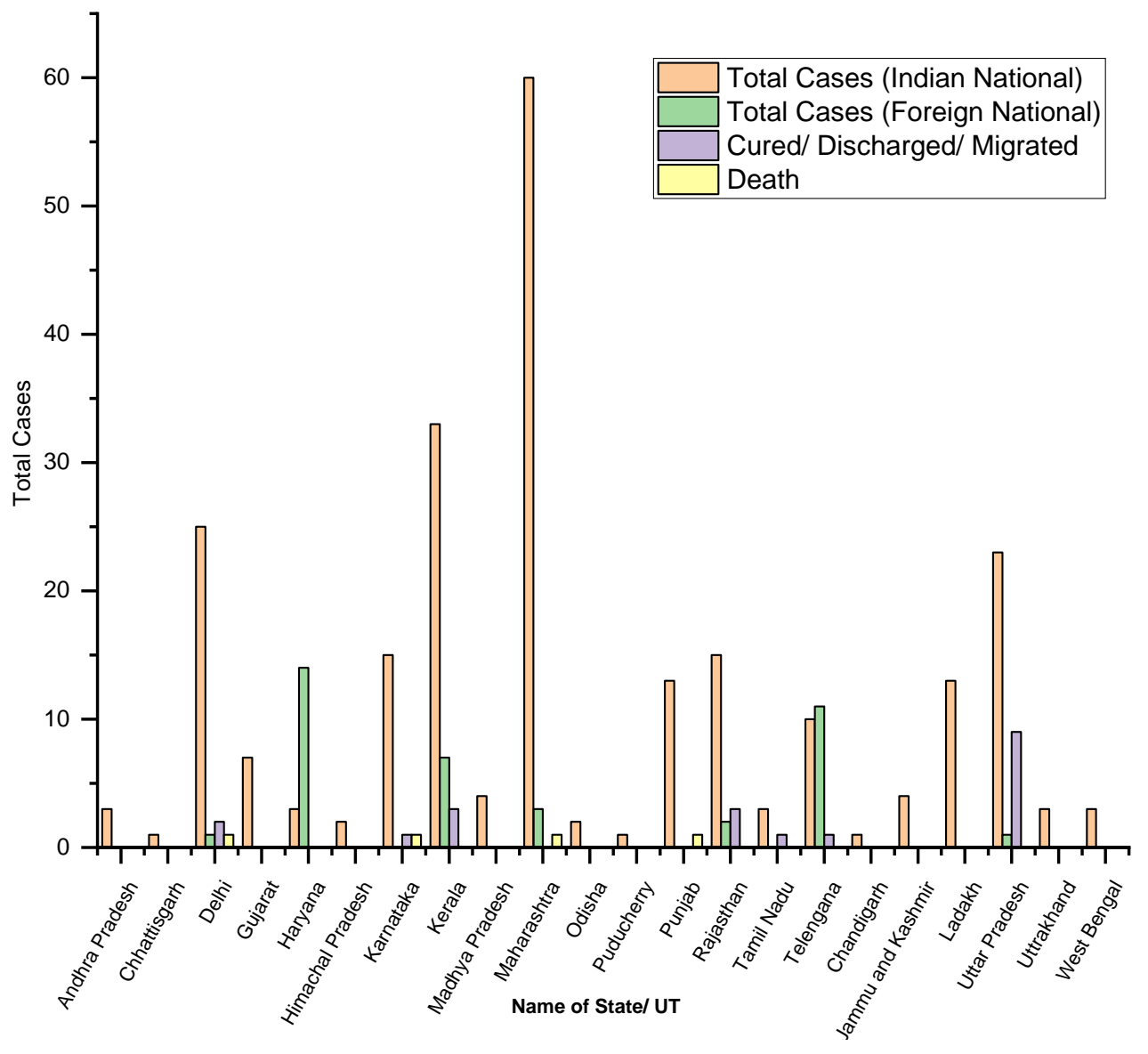


Figure 2: No. of cases in India States and UT wise

As of March 21, 2020 India having 244 of total Indian national confirmed cases of COVID-19 in which 39 are foreign nationals and 23 have been cured or migrated with 4 of total deaths. Maharashtra reported most of Indian national cases 60 which is followed by Kerala (33) and Delhi (25) [65].

\section{Prevention from COVID-19}

Since till now there is no vaccine available for this infection and also there is no approved treatment is provided by any health organization the prevention of this infection at the early stages are crucial. People suffering with the chronic underlying disease are at higher risks from the infection of COVID-19 which may cause death. The largest population country like China where the total of $16 \%$ patients was developed the severe disease with the $8.1 \%$ mortality rate. In all patients with the severe disease the co-morbidities percentage was $38.7 \%$. People with comorbidities diseases require more precautions and preventions from the COVID-19. People with infectious diseases (TB and HIV), respiratory diseases, Chronic Cardiovascular diseases (Rheumatic heart disease and Cardiomyopathy) and cancer diseases are recommended to take necessary precautions and preventions. There are some specific properties of the COVID-19 which make difficulty in prevention especially in the developing countries e.g. long incubation period of infection and non specific features of the infection. Suspected cases either imported cases or local transmission should be isolated. Proper ventilation with proper sunlight should be provided to the suspected or confirmed cases which will help to destruct the virus. Alcohol based senitizers should be used. The suspected persons should wear the masks (simple surgical masks) which will minimize the spread of virus to surroundings. Hand hygiene with alcohol based senitizer or with the soap should be done after 30-40 minutes. In the South East Asia region countries like Thailand, Nepal, Sri Lanka and India where the spread of infection is still less people should postpone the public gatherings and avoid going in crowded areas. However, Govt. of India now implementing the 144 in the major cities to avoid the gathering of the people in public places which will help to reduce the spread of infection. People should practice the cough hygiene by wearing masks, use of tissues, and coughing in sleeves rather than in hands. The use of surgical or any type of masks is still not recommended by WHO. In the most affected countries like China, Italy and Iran public has been asked to wear the proper masks in the public places where the large scale gatherings can be possible. Indian government has also shutdown the large gathering areas such as Cinema halls, shopping malls, schools and colleges to avoid the spread of COVID-19. Initially, the travel restrictions were limited up to China and people returning from the infected region of China. The suspected or infected people were taken into isolation ward for 14 days. But now as the spread of virus is growing rapidly travel restrictions have been extended to other regions also. Government of India has decided to reject the visa of 
all foreign nationals which included all type of visas to slow down the spread of infection in the country.

\section{Management and Vaccination status of COVID-19}

There is no vaccination available at the present time for the COVID-19. There are only supportive therapies are given to the suspected and infected patients which are followed by health professionals around the world. The various supportive health therapies includes the maintenance of hydration, administration of antipyretic and analgesic and mechanical ventilations is giving as the supportive therapies to the patients. In some cases interferon alpha and ribavirin has been given to the patients at the early stages of the infection. As the monotherapy mycophenolic acid is given in some cases. Still there is need of proper vaccination to cure the COVID-19 infection which is still under research. It is difficult to differentiate the COVID-19 from the other types of the respiratory viral infections by the routine lab tests or clinically so there is need of travel history of every suspect or patient to minimize the spread of infection. Till then there is need to ensure the adequate isolation for the health workers and patients to prevent the transmission of infection to the surroundings. There should be need of proper consultation if any symptoms appeared in a person related to COVID-19 and routine use of antibiotics such be avoided in the confirmed cases. In the hypoxic patients, HFNC (high flow nasal cannula), surgical face masks and provision of oxygen through the nasal pongs is indicated. Still the role of corticosteroids is unproven as the WHO is against the use of this. While Chinese health organizations have recommended the short term therapy of corticosteroids with low dose in the COVID-19. The detailed guidelines for the critical care of COVID-19 have been already published by the World health organization. As per now there is no approved treatment for the COVID-19 infection but antiviral drugs such as lopinavir-ritoanvir and ribavirin are using based on the past experience of the MERS and SARS. Based on the past experience it is found that the in SARS patient had better outcomes with the combined treatment of ribavirin and lopinavirritonavir.

\section{Initiatives taken by Govt. of India}

Govt. of India has taken many initiatives to minimize the spread of COVID-19 infection in the country. As India is the world second largest populated country but till now only 283 cases have been reported in the India. The infection rate of the COVID-19 in India remains low related to population size of the country. It is because of fast government action to quarantine the suspected people and shut down all its borders. Indian government is screening all the international travellers at the airport to avoid the spread of the infection. More than 1 million passengers have been screened till now in India in all international airports. Also, the Govt. of India has advised the Indian citizen to avoid all non-essential travel to abroad also the citizens of India have been already evacuated from the most infected countries like Italy, China, Iran and Japan. The Ministry of external affairs has also postponed the Indian cricket league. All the state authorities have shut down the schools, gyms, shopping malls and colleges till March 31, 2020. Still the 
India is facing the same challenges as other countries of the world which includes the limiting unauthorized mass gathering and fake health messages to create panic and anxiety in the public related to COVID-19. Also, the COVID-19 hits hard to the global economy. There is a great slowdown in the global economy due to COVID-19 attack which is likely to costs around \$1 trillion. The Public Health department of Maharashtra clearly said that consuming more garlic, cow urine and curry leaves would neither help in the treatment nor prevent from the COVID-19 infection. People should be focused on the hygiene practices and eat nutritious foods. The WHO report 60 clearly mentioned that the community transmission is not yet occurred in India till now there is only local transmission. The spread of COVID-19 in India can be minimize by the mass gathering and proper prevention with awareness related to infection.

\section{Practice points to be considered: Indian Perspective}

India is at stage 2 on Local transmission as per WHO report-60. The spread in India can be reduced by interrupting the human to human transmissions. Identification of suspected and infected patients will also help to minimize the spread of COVID-19. Multisectoral partnership will also help to minimize both the economic and social impact. These can be achieved by the rapid identification of the suspects and diagnosis as soon as possible. Infection prevention and controlling the spread of infection in the society with proper health care settings will help to minimize the spread of virus. Awareness raising in the Indian population through the social media and implementation of proper health measures for the travellers in India will also help to minimize the spread the COVID-19. As, risks of the COVID-19 in India is still at low level as compared to other countries but Government is taking the steps to prevent people from the COVID-19. However some points needs to be considered from the prevention points of view which are discussed below:

1. If any suspect case is found, that needs to send to isolation centre available near airport where the suspect can be taken into isolation ward for next 14 days till the test report is available.

2. Mass gathering should be avoided till the situation comes under control. All the events and public places with possibilities of mass gatherings should be closed till the situation of COVID-19 comes under control.

3. It is not possible for all the rural areas to purchase the sanitizers so alternative way of sensitizer should be provided. The agencies should aware the people of rural areas to benefits from use of sanitizer and development the low cost sanitizers at their homes.

4. All the clinics in the India should update with the recent developments in the spread of COVID-19 in the world so in the emergency time necessary steps can be taken.

5. People should distance themselves socially and should not be in touch with the other person physically, handshaking and hug should be avoided and Namaste style of greeting should be adopted. 
6. Awareness among the people related to COVID-19 should be necessary as there are many myths and misconceptions related to disease which results in the panic and anxiety of the public.

7. All the international travellers should provide their travel histories that have travelled in last 14 days. If the symptoms are seen in the person that person need be kept in isolation.

8. Cleanliness should be of paramount importance, people should clean their hands frequently with sanitizer or soap after a regular interval of time.

9. Any received international courier for should be kept outside the home for 24 hours as it may contain virus particles which can spread infection and taken in the house after sanitising it.

10. People should not buy panic unnecessarily but the precaution is the measure to prevent it.

11. People should not hide any information that can cause further problems to the person it and his/her near ones.

12. No enforcement can work as effectively as the awareness among the people can work to prevent it.

\section{Conclusion}

The new COVID-19 virus outbreak has challenged the medical, economic and public health infrastructure of many countries especially the China, Italy, Iran and Japan. The origin of n-CoV can be traced from the Huanan seafood market of the Wuhan city China. Spring festival of China provides the favourable conditions for the virus spread as Wuhan city is known as the largest transportation hub of China. Till now there is no authorized vaccination is available for the treatment of COVID-19. It is found that the incubation period for the infection is 2-14 days which is usually 4 days in maximum of cases. Worldwide 234073 infected reported cases of the COVID-19 in the world with the total of 9840 deaths (March 20, 2020). N-CoV is very similar to the SARS CoV some of the noble findings from the SARS CoV are directing the researchers to develop the drug for the $\mathrm{n}-\mathrm{CoV}$ also. Since COVID-19 has similar spread like the MERS CoV and SARS CoV it exhibits lower mortality rate. India has reported 283 cases of COVID-19 infections till now with 4 deaths. India is still at stage 2 on local transmission as per WHO report 60. WHO reported 60 clearly stated that there is no community transmission occurred in India yet which can be prevented by the avoiding mass gathering and proper screening of the people. Also, the COVID-19 hits hard to the global economy. There is a great slowdown in the global economy due to COVID-19 attack which is likely to costs around \$1 trillion. The spread of COVID-19 infection can be reduced by minimizing the $\mathrm{H}-\mathrm{H}$ transmissions. There are many research gaps in the COVID-19 research area as there is still lack of Anti-COVID-19 drug which will replace the supporting therapies for the treatment of infection. Future research work is still needed to fight with the COVID-19 disease. 


\section{References}

1. Kumar D, Malviya R, Kumar Sharma P. Corona Virus: A Review of COVID-19. EJMO 2020;4(1):8-25.

2. Holmes, K. V. (2003). SARS-associated coronavirus. New England Journal of Medicine, 348(20), 19481951.

3. Marra, M. A., Jones, S. J., Astell, C. R., Holt, R. A., Brooks-Wilson, A., Butterfield, Y. S., ... \& Cloutier, A. (2003). The genome sequence of the SARS-associated coronavirus. Science, 300(5624), 1399-1404.

4. Zhu, N., Zhang, D., Wang, W., Li, X., Yang, B., Song, J., ... \& Niu, P. (2020). A novel coronavirus from patients with pneumonia in China, 2019. New England Journal of Medicine.

5. Chan, J. F. W., Yuan, S., Kok, K. H., To, K. K. W., Chu, H., Yang, J., ... \& Tsoi, H. W. (2020). A familial cluster of pneumonia associated with the 2019 novel coronavirus indicating person-to-person transmission: a study of a family cluster. The Lancet, 395(10223), 514-523.

6. Huang, C., Wang, Y., Li, X., Ren, L., Zhao, J., Hu, Y., ... \& Cheng, Z. (2020). Clinical features of patients infected with 2019 novel coronavirus in Wuhan, China. The Lancet, 395(10223), 497-506.

7. Holshue, M. L., DeBolt, C., Lindquist, S., Lofy, K. H., Wiesman, J., Bruce, H., ... \& Diaz, G. (2020). First case of 2019 novel coronavirus in the United States. New England Journal of Medicine.

8. Backer, J. A., Klinkenberg, D., \& Wallinga, J. (2020). Incubation period of 2019 novel coronavirus (2019$\mathrm{nCoV}$ ) infections among travellers from Wuhan, China, 20-28 January 2020. Eurosurveillance, 25(5).

9. Bryson-Cahn, C., Duchin, J., Makarewicz, V. A., Kay, M., Rietberg, K., Napolitano, N., ... \& Lynch, J. B. (2020). A Novel Approach for a Novel Pathogen: using a home assessment team to evaluate patients for 2019 novel coronavirus (SARS-CoV-2). Clinical Infectious Diseases.

10. Chertow, D. S., \& Kindrachuk, J. (2020). Influenza, Measles, SARS, MERS, and Smallpox. In Highly Infectious Diseases in Critical Care (pp. 69-96). Springer, Cham.

11. Jaimes, J. A., Millet, J. K., Stout, A. E., André, N. M., \& Whittaker, G. R. (2020). A Tale of Two Viruses: The Distinct Spike Glycoproteins of Feline Coronaviruses. Viruses, 12(1), 83.

12. Munster, V. J., Koopmans, M., van Doremalen, N., van Riel, D., \& de Wit, E. (2020). A novel coronavirus emerging in China-key questions for impact assessment. New England Journal of Medicine, 382(8), 692694.

13. Fung, S. Y., Yuen, K. S., Ye, Z. W., Chan, C. P., \& Jin, D. Y. (2020). A tug-of-war between severe acute respiratory syndrome coronavirus 2 and host antiviral defence: lessons from other pathogenic viruses. Emerging Microbes \& Infections, 9(1), 558-570.

14. Woo, P. C., Lau, S. K., Tsoi, H. W., Huang, Y., Poon, R. W., Chu, C. M., ... \& Cheng, V. C. (2005). Clinical and molecular epidemiological features of coronavirus HKU1-associated community-acquired pneumonia. The Journal of infectious diseases, 192(11), 1898-1907.

15. Bastien, N., Anderson, K., Hart, L., Caeseele, P. V., Brandt, K., Milley, D., ... \& Li, Y. (2005). Human coronavirus NL63 infection in Canada. The Journal of infectious diseases, 191(4), 503-506.

16. Brian, D. A., \& Baric, R. S. (2005). Coronavirus genome structure and replication. In Coronavirus replication and reverse genetics (pp. 1-30). Springer, Berlin, Heidelberg.

17. World Health Organization Director-General's opening remarks at the media briefing on COVID-19 - 24 February 2020 https://www.who.int/dg/speeches/detail/who-director-general-s-opening-remarks-at-themedia-briefing-on-covid-19---24-february-2020 (Accessed on February 26, 2020).

18. National Health Commission of the People's Republic of China. New coronavirus cases rise to 571 in Chinese mainland. January 23, 2020. http://en.nhc.gov.cn/2020-01/23/c_76004.htm (Accessed on January 23, 2020).

19. European Centre for Disease Prevention and Control. Novel coronavirus in China. https://www.ecdc.europa.eu/en/novel-coronavirus-china (Accessed on January 23, 2020).

20. Zhou, P., Yang, X. L., Wang, X. G., Hu, B., Zhang, L., Zhang, W., ... \& Chen, H. D. (2020). A pneumonia outbreak associated with a new coronavirus of probable bat origin. Nature, 1-4. 
21. Gorbalenya, A. E. (2020). Severe acute respiratory syndrome-related coronavirus-The species and its viruses, a statement of the Coronavirus Study Group. BioRxiv.

22. Na, Z., Dingyu, Z., \& Wenling, W. (2020). A Novel Coronavirus from Patients with Pneumonia in China, 2019.[J]. N. Engl. J. Med, 382, 727-733.

23. Lu, R., Zhao, X., Li, J., Niu, P., Yang, B., Wu, H., ... \& Bi, Y. (2020). Genomic characterisation and epidemiology of 2019 novel coronavirus: implications for virus origins and receptor binding. The Lancet, 395(10224), 565-574.

24. Perlman, S. (2020). Another decade, another coronavirus.

25. Tang, X., Wu, C., Li, X., Song, Y., Yao, X., Wu, X., ... \& Cui, J. (2020). On the origin and continuing evolution of SARS-CoV-2. National Science Review.

26. Pung, R., Chiew, C. J., Young, B. E., Chin, S., Chen, M. I., Clapham, H. E., ... \& Low, M. (2020). Investigation of three clusters of COVID-19 in Singapore: implications for surveillance and response measures. The Lancet.

27. Yuan, H., Cao, X., Ji, X., Du, F., Zhou, X., He, J., ... \& Zhu, Y. (2020). A Current Emerging Respiratory Infection: Epidemiological and Clinical Characteristics, Diagnosis and Treatments of COVID19. Diagnosis and Treatments of COVID-19 (3/6/2020).

28. Goh, G. K. M., Dunker, A. K., Foster, J. A., \& Uversky, V. N. (2020). Rigidity of the Outer Shell Predicted by a Protein Intrinsic Disorder Model Sheds Light on the COVID-19 (Wuhan-2019-nCoV) Infectivity.

29. Cai, J., Sun, W., Huang, J., Gamber, M., Wu, J., \& He, G. (2020). Indirect Virus Transmission in Cluster of COVID-19 Cases, Wenzhou, China, 2020. Emerging infectious diseases, 26(6).

30. Report of the WHO-China Joint Mission on Coronavirus DIsease 2019 (COVID-2019). February 16-24, 2020. http://www.who.int/docs/default-source/coronaviruse/who-china-joint-mission-on-covid-19-finalreport.pdf (Accessed on March 04, 2020).

31. Burke, R. M. (2020). Active Monitoring of Persons Exposed to Patients with Confirmed COVID-19United States, January-February 2020. MMWR. Morbidity and Mortality Weekly Report, 69.

32. Rothe, C., Schunk, M., Sothmann, P., Bretzel, G., Froeschl, G., Wallrauch, C., ... \& Seilmaier, M. (2020). Transmission of 2019-nCoV infection from an asymptomatic contact in Germany. New England Journal of Medicine.

33. Kupferschmidt K. Study claiming new coronavirus can be transmitted by people without symptoms was flawed. Science. February 3, 2020. https://www.sciencemag.org/news/2020/02/paper-non-symptomaticpatient-transmitting-coronavirus-wrong (Accessed on February 04, 2020).

34. Bai, Y., Yao, L., Wei, T., Tian, F., Jin, D. Y., Chen, L., \& Wang, M. (2020). Presumed asymptomatic carrier transmission of COVID-19. Jama.

35. Hu, Z., Song, C., Xu, C., Jin, G., Chen, Y., Xu, X., ... \& Wang, J. (2020). Clinical characteristics of 24 asymptomatic infections with COVID-19 screened among close contacts in Nanjing, China. Science China Life Sciences, 1-6.

36. Li, Z., Yi, Y., Luo, X., Xiong, N., Liu, Y., Li, S., ... \& Zhang, Y. (2020). Development and Clinical Application of A Rapid IgM-IgG Combined Antibody Test for SARS-CoV-2 Infection Diagnosis. Journal of medical virology.

37. Centers for Disease Control and Prevention. Interim Clinical Guidance for Management of Patients with Confirmed 2019 Novel Coronavirus (2019-nCoV) Infection, Updated February 12, 2020. https://www.cdc.gov/coronavirus/2019-ncov/hcp/clinical-guidance-management-patients.html (Accessed on February 14, 2020).

38. Tang, A., Tong, Z. D., Wang, H. L., Dai, Y. X., Li, K. F., Liu, J. N., ... \& Yan, J. B. (2020). Detection of Novel Coronavirus by RT-PCR in Stool Specimen from Asymptomatic Child, China. Emerging infectious diseases, 26(6).

39. Report of the WHO-China Joint Mission on Coronavirus DIsease 2019 (COVID-2019). February 16-24, 2020. http://www.who.int/docs/default-source/coronaviruse/who-china-joint-mission-on-covid-19-finalreport.pdf (Accessed on March 04, 2020). 
40. Guan, W. J., Ni, Z. Y., Hu, Y., Liang, W. H., Ou, C. Q., He, J. X., ... \& Du, B. (2020). Clinical characteristics of coronavirus disease 2019 in China. New England Journal of Medicine.

41. Ralph, R., Lew, J., Zeng, T., Francis, M., Xue, B., Roux, M., ... \& Kelvin, D. J. (2020). 2019-nCoV (Wuhan virus), a novel Coronavirus: human-to-human transmission, travel-related cases, and vaccine readiness. The Journal of Infection in Developing Countries, 14(01), 3-17.

42. Jiang, F., Deng, L., Zhang, L., Cai, Y., Cheung, C. W., \& Xia, Z. (2020). Review of the clinical characteristics of coronavirus disease 2019 (COVID-19). Journal of General Internal Medicine, 1-5.

43. Sohrabi, C., Alsafi, Z., O’Neill, N., Khan, M., Kerwan, A., Al-Jabir, A., ... \& Agha, R. (2020). World Health Organization declares global emergency: A review of the 2019 novel coronavirus (COVID19). International Journal of Surgery.

44. Fang, Z., Yi, F., Wu, K., Lai, K., Sun, X., Zhong, N., \& Liu, Z. (2020). Clinical Characteristics of 2019 Coronavirus Pneumonia (COVID-19): An Updated Systematic Review. medRxiv.

45. Rothan, H. A., \& Byrareddy, S. N. (2020). The epidemiology and pathogenesis of coronavirus disease (COVID-19) outbreak. Journal of Autoimmunity, 102433.

46. Pan, F., Ye, T., Sun, P., Gui, S., Liang, B., Li, L., ... \& Zheng, C. (2020). Time course of lung changes on chest CT during recovery from 2019 novel coronavirus (COVID-19) pneumonia. Radiology, 200370.

47. Zhang, L., \& Liu, Y. (2020). Potential interventions for novel coronavirus in China: a systematic review. Journal of medical virology.

48. Li, Q., Guan, X., Wu, P., Wang, X., Zhou, L., Tong, Y., ... \& Xing, X. (2020). Early transmission dynamics in Wuhan, China, of novel coronavirus-infected pneumonia. New England Journal of Medicine.

49. Liu, Y. C., Liao, C. H., Chang, C. F., Chou, C. C., \& Lin, Y. R. (2020). A locally transmitted case of SARS-CoV-2 infection in Taiwan. New England Journal of Medicine, 382(11), 1070-1072.

50. Wei, M., Yuan, J., Liu, Y., Fu, T., Yu, X., \& Zhang, Z. J. (2020). Novel coronavirus infection in hospitalized infants under 1 year of age in China. Jama.

51. World Health Organization. Coronavirus disease 2019 (COVID-19) Situation Report - 28. https://www.who.int/docs/default-source/coronaviruse/situation-reports/20200217-sitrep-28-covid19.pdf?sfvrsn=a19cf2ad_2 (Accessed on February 18, 2020).

52. Japanese National Institute of Infectious Diseases. Field Briefing: Diamond Princess COVID-19 Cases, 20 Feb Update. https://www.niid.go.jp/niid/en/2019-ncov-e/9417-covid-dp-fe-02.html (Accessed on March 01, 2020).

53. Wang, Y., Liu, Y., Liu, L., Wang, X., Luo, N., \& Ling, L. (2020). Clinical outcome of 55 asymptomatic cases at the time of hospital admission infected with SARS-Coronavirus-2 in Shenzhen, China. The Journal of Infectious Diseases.

54. Hu, Z., Song, C., Xu, C., Jin, G., Chen, Y., Xu, X., ... \& Wang, J. (2020). Clinical characteristics of 24 asymptomatic infections with COVID-19 screened among close contacts in Nanjing, China. Science China Life Sciences, 1-6.

55. Yang, X., Yu, Y., Xu, J., Shu, H., Liu, H., Wu, Y., ... \& Wang, Y. (2020). Clinical course and outcomes of critically ill patients with SARS-CoV-2 pneumonia in Wuhan, China: a single-centered, retrospective, observational study. The Lancet Respiratory Medicine.

56. Wu, Z., \& McGoogan, J. M. (2020). Characteristics of and important lessons from the coronavirus disease 2019 (COVID-19) outbreak in China: summary of a report of 72314 cases from the Chinese Center for Disease Control and Prevention. Jama.

57. Wang, D., Hu, B., Hu, C., Zhu, F., Liu, X., Zhang, J., ... \& Zhao, Y. (2020). Clinical characteristics of 138 hospitalized patients with 2019 novel coronavirus-infected pneumonia in Wuhan, China. Jama.

58. Chen, N., Zhou, M., Dong, X., Qu, J., Gong, F., Han, Y., ... \& Yu, T. (2020). Epidemiological and clinical characteristics of 99 cases of 2019 novel coronavirus pneumonia in Wuhan, China: a descriptive study. The Lancet, 395(10223), 507-513. 
59. Centers for Disease Control and Prevention. Severe outcomes among patients with Coronavirus Disease 2019 (COVID-19) - United States, February 12-March 16, 2020. https://www.cdc.gov/mmwr/volumes/69/wr/mm6912e2. (Accessed on March 19, 2020).

60. Cui, Y., Tian, M., Huang, D., Wang, X., Huang, Y., Fan, L., ... \& Wu, Y. (2020). A 55-Day-Old Female Infant infected with COVID 19: presenting with pneumonia, liver injury, and heart damage. The Journal of Infectious Diseases.

61. KCDC. Updates on COVID-19 in Korea. March 14, 2020. https://www.cdc.go.kr/board/board.es?mid=a30402000000\&bid=0030 (Accessed on March 14, 2020).

62. Liu, W., Zhang, Q., Chen, J., Xiang, R., Song, H., Shu, S., ... \& Wu, P. (2020). Detection of Covid-19 in Children in Early January 2020 in Wuhan, China. New England Journal of Medicine.

63. Wang, D., Hu, B., Hu, C., Zhu, F., Liu, X., Zhang, J., ... \& Zhao, Y. (2020). Clinical characteristics of 138 hospitalized patients with 2019 novel coronavirus-infected pneumonia in Wuhan, China. Jama.

64. World Health Organization. (2020). Coronavirus disease 2019 ( COVID-19): situation report, 60

65. Novel corona virus https://webcache.googleusercontent.com/search?q=cache:https://mohfw.gov.in/. (Accessed on March 21, 2020) 